exhibits. It is well written, and the reader with some knowledge of physics will find that it gives an accurate summary of the history of the electron during the past fifty years. The subjects dealt with include: the discovery of the electron and the measurement of its charge; the thermionic valve and the cathode ray tube; the photo-electric effect and devices; atomic structure; electron diffraction; $\mathrm{X}$-rays; and the conduction of electrons in gases and solids. It is a pity that no illustrations of the actual exhibits are given. Doubtless a third part to the handbook, similar to that produced for the 'low-temperature' exhibition several years ago, with photographs of the exhibits and exhibition, would receive a welcome. The exhibition will remain open to the public for three months.

\section{Automatic Control on Atlantic Flight}

A U.S. Air Force "Skymaster" transport aircraft flew from Stephenville, Newfoundland, to Brize Norton R.A.F. Station in Oxfordshire, on September 22 , a distance of 2,400 miles across the Atlantic, including taking off and landing, without being controlled in any way by the crew on board. The machine was commanded by Colonel J. N. Gillespie of the U.S. Air Force, and carried a number of scientific observers as well as the normal crew. The apparatus automatically controls the take-off and climb to an arranged height. It then homes on a beam sent out by a radio beacon. In this case these came from two successive ships on the way across, and then from Brize Norton. Finally, it sets the machine into the required glide, lands and brakes. In the United States the system is understandably described as 'push button flying'.

The real significance of this system lies in the ability to make landings at the end of the flight. Automatic control of direction during a flight has been in use successfully for some time. A flight can now be commenced without fear as to what the weather conditions will be at the end of it. The radio control is independent of the weather and can land a machine under conditions in which human control would be impossible; in bad visibility, for example. The apparatus is such that it can be fitted to any aircraft of sufficient capacity; in fact, the machine which has just crossed the Atlantic was a standard Skymaster of the U.S. Air Force. The system would not be applicable to bombing raids, as it depends upon radio co-operation from the terminal point, which would not be available from the enemy territory.

\section{Correspondence of Isaac Newton}

Although Isaac Newton is acclaimed as the greatest leader of scientific thought that the world has known, there exists no satisfactory collected edition of his works. The Council of the Royal Society has decided to make a first step in the arduous undertaking of preparing such an edition by producing in a worthy form the collected correspondence of Newton, which will comprise letters written by him and the replies to them. Prof. H. W. Turnbull has undertaken the editorship of this work. The Council of the Royal Society has entrusted the immediate organisation of the publication of the Newton correspondence to a sub-committee of the Society, under the chairmanship of Prof. E. N. da C. Andrade. It is hoped that learned institutions, museums, libraries and collections will collaborate in the work, by notifying the assistant secretary of the Royal
Society of any letters of Newtonian interest that they may possess, and by lending the letters to the Society for a brief period or by arranging with the Society for photographic copies to be made.

\section{Overseas Broadcast of the British Association Meeting}

A serious attempt was made by the B.B.C. to give listeners an account of the recent meeting of the British Association in Dundee, by bringing representative speakers to the microphone every day. A descriptive broadcast on Dundee and St. Andrews was also given in the B.B.C. overseas service to Germany on September 19, and repeated on September 23. The broadcast, recorded in German, included an account of the Dundee shipyards and of visits to marmalade and jute factories. There were also interviews at Dundee with Prof. J. D. Cockcroft on atomic energy, Sir Robert WatsonWatt on radar and Dr. E. B. Chain on penicillin. The account of the University of St. Andrews and of the ancient buildings of the city included interviews with Dr. C. T. Carr, lecturer in German, and Dr. John Read, professor of chemistry, whose reference to alchemical music was illustrated by a gramophone reproduction of one of Count Michael Maier's canons from "Atalanta Fugiens" (1618).

\section{Heredity}

RECENTLY there has appeared the first number of the new journal, Heredity, devoted, as its name indicates, to genetics (Nature, 159,$599 ; 1947)$. In the past fifty years, this science has seen an expanding flow of publications - a flow which the War did little to check. Before 1939 this increase was matched by the increasing number of journals which offered facilities for the publication of findings in genetics; but far from the increase in means of publication continuing, the War has led to a reduction in the number of genetics journals in Europe. The appearance of a new one is therefore particularly welcome at the present time. Heredity is jointly edited by Dr. C. D. Darlington and Prof. R. A. Fisher, and it is published by Messrs. Oliver and Boyd of London and Edinburgh. Its international nature is emphasized by the board of five collaborating editors, of whom three are from Europe and two from the United States. The editorial policy is a liberal one both in the types of articles which will be accepted and in the fields from which they will be drawn. Historical, review and critical contributions will find their places beside the records of new research ; and cytology, statistics, biochemistry, evolutionary theory and breeding work will all be accepted in so far as they are related to genetics. The new journal is to appear three times a year.

The first number of Heredity well illustrates how this editorial policy is put into practice. It contains ten articles, covering a wide field in their nature, in their subject-matter and in the countries from which they originate. The first two form a novel departure and one which should do much towards overcoming the consequences of difficulty in communication during the war years. These are respectively, a summary of genetical research in Great Britain during 1939-45, and a bibliography of German and Italian research during the same period. Though running to some six hundred titles, this list is not complete in its German section, and a supplementary bibliography is promised. Two short papers describe a new gene 